\title{
Fatal Enteritis Necroticans (Pigbel) in a Diabetic Adult
}

\author{
Lizhen Gui, M.D., Ph.D., Charu Subramony, M.D., Jonathan Fratkin, M.D., Michael D. Hughson, M.D. \\ Department of Pathology, University of Mississippi Medical Center, Jackson, Mississippi
}

\begin{abstract}
Enteritis necroticans is a segmental necrotizing infection of the jejunum and ileum caused by Clostridium perfringens, Type $\mathrm{C}$. The disease occurs sporadically in parts of Asia, Africa, and the South Pacific, where it primarily affects children with severe protein malnutrition. The disease is extremely rare in developed countries, where it has been seen primarily in diabetics. Two cases have previously been reported in the United States, one in a child with poorly controlled Type 1 diabetes. A 66-yearold woman with a 12-year history of Type 2 diabetes mellitus developed severe abdominal pain and bloody diarrhea after eating a meal of turkey sausage. She died unattended at home. An autopsy showed peritonitis and segmental necrosis of the jejunum and ileum. Microscopic examination showed Gram-positive club-shaped bacilli consistent with Clostridia coating a necrotic mucosa. Products of $c p a$ and $c p b$ genes of $C$. perfringens, Type $C$ were identified in the necrotic jejunum by polymerase chain reaction amplification.
\end{abstract}

KEY WORDS: Clostridium perfringens, Enteritis necroticans, Pigbel, Type C.

Mod Pathol 2002;15(1):66-70

Enteritis necroticans is a life-threatening infectious disease caused by Clostridium perfringens, Type C, a $\beta$ toxin-producing strain of clostridia. The disease, which is characterized by segmental necrosis of the proximal jejunum, is associated with a high mortality rate if not diagnosed early and treated with antibiotics or, if advanced, with antibiotics and surgical excision of necrotic bowel. It was first reported in Northern Germany after World War II among previously starved children and adults who ate large meals of meats and vegetables. At that time, the disease was called Darmbrand, meaning "burnt bowels" $(1,2)$. Because of the unique heat

Copyright $(2002$ by The United States and Canadian Academy of Pathology, Inc.

VOL. 15, NO. 1, P. 66, 2002 Printed in the U.S.A.

Date of acceptance: September 21, 2001.

Address reprint requests to: Charu Subramony, M.D., Department of Pathology, University of Mississippi Medical Center, 2500 North State Street, Jackson, MS 39216-4505; e-mail: csubramony@pathology .umsmed.edu; fax: 601-984-1531. resistance of the spores, the causative organism was initially identified as $C$. perfringens, Type F (3), which was later found to be identical to C. perfringens, Type C (4). This disease was prevalent between 1944 and 1948, but as the nutritional status of the population improved, the condition disappeared in Europe (2).

In 1963, Murrell and Roth (5) reported a similar disease in 17 patients from the Highlands of Papua New Guinea. The patients were mostly male children and young adults, ranging in age from 2 to 36 years, who presented with severe abdominal pain after ceremonial feasting on huge quantities of sweet potatoes and inadequately cooked pork contaminated with pig intestines. C. perfringens was isolated from the meat and from the stools of seven patients. C. perfringens, Type $\mathrm{C}$ was isolated from resected jejunal segments of affected patients, establishing the organism as the causative agent. This disease was called "pigbel," a pidgin English term for abdominal pain after a pig feast $(6,7)$.

Epidemiological studies indicated that this disease accounted for $10 \%$ of all deaths and for $50 \%$ of deaths in children between 6 and 10 years of age in the highlands of Papua New Guinea $(8,9)$. A marked reduction in mortality and morbidity was obtained by treating the affected patients with Type $C$ antiserum (10). When the children of New Guinea were vaccinated with a $\beta$ toxoid, an 8 -fold decrease in annual incidence of the disease was achieved (8).

Only a few cases have been identified in developed countries (11-15). In the United States, a case of enteritis necroticans was recently reported in a 12-year-old boy in Georgia with poorly controlled diabetes who ate pig intestines (chitterlings). The patient recovered completely after resection of the necrotic segment of bowel (15). We report a fatal case in the southeastern United States of enteritis necroticans caused by $C$. perfringens, Type C, in an adult with Type 2 diabetes mellitus.

\section{CASE REPORT}

Family members found a 66-year-old AfricanAmerican woman unresponsive at home. She was taken to the University of Mississippi Medical Cen- 
ter Emergency Room, where she was pronounced dead upon arrival. Four days before, during an automobile trip home to Mississippi from Chicago, she had bought $3 \mathrm{lb}$ of turkey sausage locally processed in Illinois. Approximately 65 hours before she died, she had eaten breakfast at home with her husband and daughter. Boiled turkey sausage, along with some toast, egg, and corn meal were consumed. Fifteen hours later, she complained of abdominal pain and diarrhea and took Imodium. The diarrhea became bloody within 6 hours after the onset of abdominal pain. She continued to have diarrhea when last seen alive but did not seek medical attention. Her husband also complained of one or two loose stools that resolved spontaneously. Her daughter complained of stomach discomfort but had no other symptoms. The patient had a 12-year history of Type 2 diabetes mellitus and long-term hypertension. She monitored her own blood glucose on a daily basis. She was only slightly overweight, and her diabetes was considered to be adequately controlled.

An autopsy was performed. The abdomen was distended. Approximately $400 \mathrm{~mL}$ of straw-colored fluid was noted in the peritoneal cavity. The bowel loops from the jejunum to cecum were moderately dilated. The serosa of segments of small bowel was dusky red and coated with a yellow-green serosal exudate but showed no perforation. The jejunum and proximal ileum revealed segmental mucosal and transmural necrosis with pseudomembranes attached to the necrotic mucosa (Fig. 1). The terminal ileum showed segmental mucosal necrosis without pseudomembranes. Gaseous cysts of pneumatosis intestinalis were present focally in the jejunum. The serosa showed a thin layer of acute inflammatory exudate. Other significant findings included severe atherosclerotic coronary artery dis-
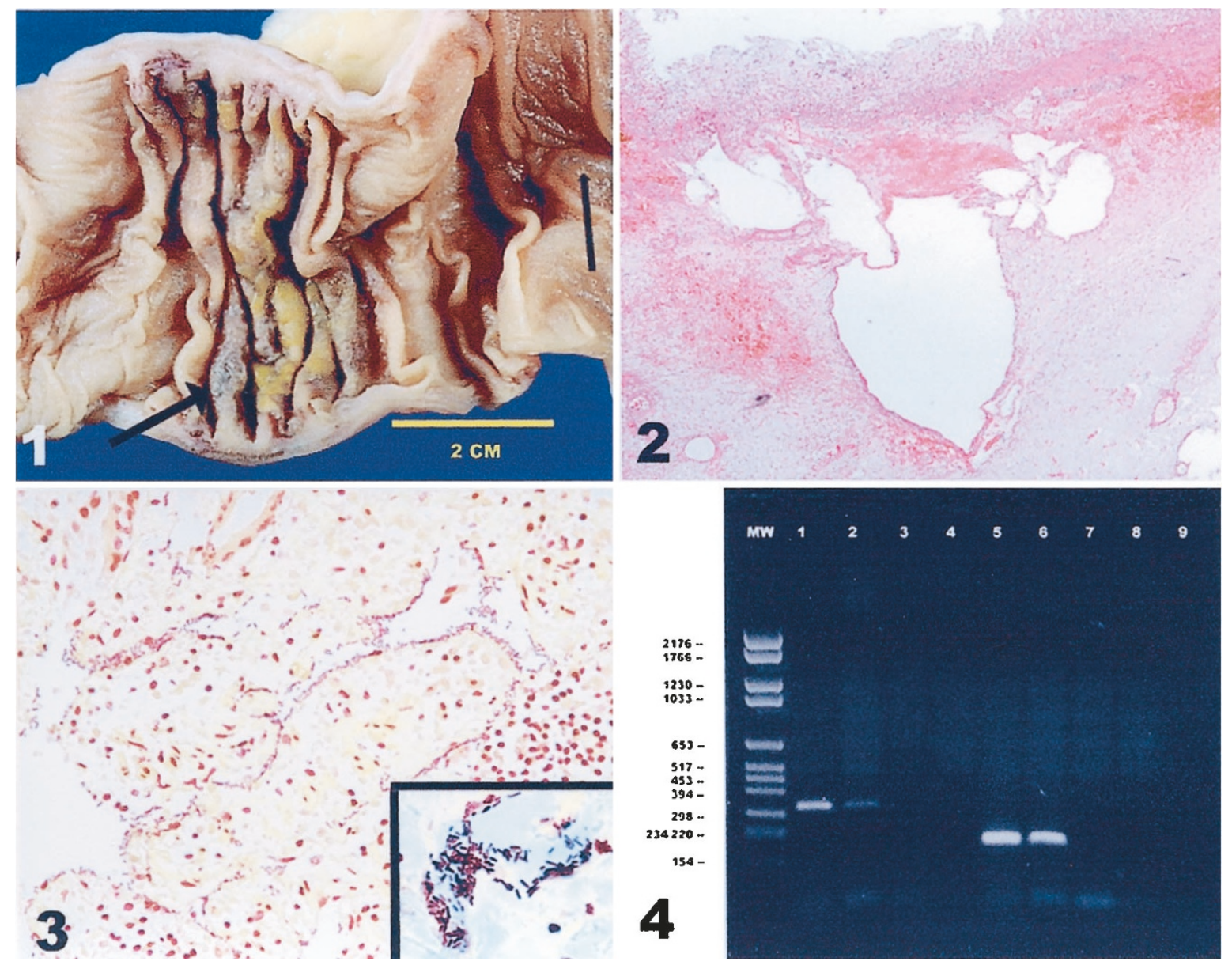

FIGURE 1. Segment of jejunum showing mucosal necrosis and pseudomembrane (large arrow) and pneumatosis (small arrow).

FIGURE 2. Necrotic mucosa and submucosa with pneumatosis (hematoxylin and eosin, original magnification, $40 \times$ )

FIGURE 3. Numerous Gram-positive organisms on the surface of the necrotic jejunal mucosa (Brown and Brennan's Gram stain; original magnification, $400 \times)$. Inset, original magnification, $1000 \times$

FIGURE 4. Electrophoresis of DNA fragments produced by polymerase chain reaction using primers for $c p a$ and $c p b$ genes. MW is the DNA standards (from the top, 176, 1766, 1230, 1033, 653, 517, 453, 394, 298, 234/220, and 154 bp); Lanes 1 and 2 show the amplification of cpa in positive-control strain (ATCC 51880) and jejunum of the patient, respectively; Lane 3 shows no amplification in small bowel of a patient who died of unrelated disease; Lane 4 has no template; Lanes 5 and $\mathbf{6}$ show the amplification of $c p b$ in positive-control strain (ATCC 51880) and jejunum of the patient, respectively; Lane 7 shows no amplification in the small bowel of a patient who died of unrelated disease; Lane 8 has no template. The bands at the bottom of each lane are unused primers. 
ease with significant narrowing of the left anterior descending artery and left ventricular hypertrophy. The superior mesenteric artery and its branches showed no significant atherosclerosis.

Microscopic examination of the jejunum and ileum revealed transmural necrosis with hemorrhage and pneumatosis (Fig. 2) and acute fibrinous peritonitis. Gram-stained sections showed numerous large, club-shaped, Gram-positive rods attached to a necrotic mucosa (Fig. 3). The morphology of these organisms was consistent with Clostridium species. DNA extracted from formalin-fixed jejunal tissue was amplified by polymerase chain reaction (PCR), using primers specific for $c p a$ and $c p b$ genes of $C$. perfringens, Type $C(16,17)$. The final reactions were electrophoresed on $1.5 \%$ agarose gel and stained with ethidium bromide. The presence of $c p a$ and $c p b$ gene products in the PCR reactions confirmed the presence of $C$. perfringens, Type $\mathrm{C}$ (Fig. 4). DNA from the bowel tissue of a patient who died of an unrelated condition was used as a negative control. Microscopically, the kidneys demonstrated an advanced diabetic nephropathy, with severe microvascular disease. The pancreas showed hyalinization of the islets of Langerhans, hyaline thickening of the walls of the interlobular arteries of the pancreas, and moderate atherosclerosis of the splenic artery.

Portions of the sausage that had been consumed by the patient before her illness and that had been stored at $-20^{\circ} \mathrm{C}$ was obtained from the family and cultured for clostridial organisms. The cultures were negative.

\section{DISCUSSION}

C. perfringens, a Gram-positive bacillus, can be classified into four subtypes on the basis of four major toxins produced by the organisms. Type A organisms produce $\alpha$ toxin; Type B, $\alpha, \beta$, and $\varepsilon$ toxins; Type C, $\alpha$ and $\beta$ toxins; and Type D, $\alpha$ and $\varepsilon$ toxins. Type A organisms cause gas gangrene and are a major cause of food poisoning throughout the world. Type C organisms cause enteritis necroticans. Although Type $\mathrm{C}$ is widely distributed in the soil and in the stools of animals and man $(4,13)$, enteritis necroticans is mainly confined to areas of the world in which there is severe protein malnutrition. Types B and D are not known to cause disease in humans. The gene for the $\alpha$ toxin is chromosomal and encodes a phospholipase that hydrolyses the membrane phospholipid of erythrocytes, endothelial cells, and muscle cells. The $\beta$ toxin of $C$. perfringens, Type $\mathrm{C}$, is carried on a plasmid and encodes a highly trypsin-sensitive protein that causes intestinal necrosis (4). The genes for the $\alpha$ and $\beta$ toxins of $C$. perfringens,
Type C, are designated $c p a$ and $c p b$, respectively. The PCR amplification of $c p a$ and $c p b$ products with gene specific primers allows the identification of $C$. perfringens, Type $\mathrm{C}$, and its discrimination from Type A $(15,16)$.

Our patient developed abdominal pain and diarrhea 15 hours after eating a meal containing turkey sausage and died 60 hours after the onset of symptoms with Gram-positive, club-shaped bacilli on the surface of a necrotic jejunum. The large number of organisms found suggests that the organism is the etiology of the necrosis rather than a secondary invader of ischemic necrotic tissues. The demonstration of the PCR products of the $c p a$ and $c p b$ genes positively identified the etiologic agent to be C. perfringens, Type C. Although an attempt to culture the organism from the turkey sausage was unsuccessful, it remains the most likely source of the organism. C. perfringens, Type $\mathrm{C}$, has been reported in samples obtained from domestic animals from Indiana, Michigan, and Minnesota (16). Other family members who had eaten the sausage suffered a self-limited gastrointestinal illness.

An experimental model of enteritis necroticans was developed in guinea pigs by injecting viable cultures of $C$. perfringens, Type C, into the jejunum (18). The lesions could not be produced in the animals when the cultures were given orally or instilled into the stomach because of destruction of the $C$. perfringens, Type $C \beta$ toxin by gastric acid and pepsin and pancreatin (18). However, when cultures were instilled into the stomach with naturally occurring protease inhibitors in sweet potato or soybean flour or if the animals were given lowprotein diets, necrotic lesions developed in the jejunum. Also, children of New Guinea who developed enteritis necroticans had a higher rate of Ascaris lumbricoides infection of the gut than the general population. A potent trypsin inhibitor, secreted by the parasite to prevent its own digestion, prevents degradation of the clostridial toxins (8). These experiments and the virtual limitation of the disease to protein-malnourished populations, with or without parasitic infection of the gut, suggest that in addition to ingestion of contaminated foods, the pathogenesis of enteritis necroticans requires endogenous and exogenous trypsin inhibitors or a lack of protease secretion in the gut.

Since 1984, two cases of C. perfringens, Type C enteritis necroticans have been reported in the United States, two in England, and one in Australia (Table 1: 11-15). Three of these five patients had Type 1 or Type 2 diabetes mellitus (11-13, 15). One of the nondiabetics was a vegetarian who consumed large amounts of sweet potatoes, soybeans, and peanut sauce, all of which contain trypsin inhibitors that were thought to have predisposed the patient to the disease (14). Two additional diabetic 
TABLE 1. Cases of Enteritis Necroticans caused by Clostridium Perfringens Type C Infection Reported in the Literature and Current Case

\begin{tabular}{|c|c|c|c|c|c|c|}
\hline $\begin{array}{c}\text { Ref. } \\
\#\end{array}$ & $\begin{array}{l}\text { Age } \\
\text { (y)/Sex }\end{array}$ & $\begin{array}{l}\text { History and Type } \\
\text { of Diabetes }\end{array}$ & $\begin{array}{l}\text { Food Eaten before } \\
\text { Symptoms }\end{array}$ & Outcome & Pathology & $\begin{array}{c}\text { Method of Identification of } C \text {. } \\
\text { Perfringens }\end{array}$ \\
\hline 11 & $24 / \mathrm{M}$ & Type I, controlled & $\begin{array}{l}\text { No special food eaten } \\
\text { before admission }\end{array}$ & $\begin{array}{l}\text { Died } 24 \text { hours after } \\
\text { admission }\end{array}$ & $\begin{array}{l}\text { Autopsy: serosanguinous } \\
\text { peritoneal fluid, extensive } \\
\text { mucosal and focal } \\
\text { transmural necrosis of small } \\
\text { bowel and colon, } \\
\text { pneumatosis, and peritonitis }\end{array}$ & $\begin{array}{l}\text { Gram stain and culture of stool. } \\
\text { Gram stain of necrotic } \\
\text { mucosa from autopsy tissue }\end{array}$ \\
\hline 12 & $44 / \mathrm{M}$ & $\begin{array}{l}\text { Type II, poorly } \\
\text { controlled }\end{array}$ & $\begin{array}{l}\text { Pork, prawns, } \\
\text { chicken, meat, and } \\
\text { seafood }\end{array}$ & $\begin{array}{l}\text { Excision of } 15 \mathrm{~cm} \text { of } \\
\text { jejunum \& ileum } 4 \\
\text { d after admission }\end{array}$ & $\begin{array}{l}\text { Ascites, mucosal, and } \\
\text { transmural necrosis of } \\
\text { jejunum and ileum; patchy } \\
\text { mucosal inflammation of } \\
\text { duodenum and upper } \\
\text { jejunum }\end{array}$ & Gram stain of feces and culture \\
\hline 13 & $53 / \mathrm{F}$ & No & Chicken, sweet potato & $\begin{array}{l}\text { Excision of } 75 \mathrm{~cm} \text { of } \\
\text { small bowel, } 4 \text { days } \\
\text { after admission }\end{array}$ & $\begin{array}{l}\text { Cloudy peritoneal fluid, } 15 \mathrm{~cm} \\
\text { of jejunum showed patchy } \\
\text { mucosal necrosis; distal } 75 \\
\text { cm of ileum necrotic }\end{array}$ & $\begin{array}{l}\text { Blood and peritoneal fluid } \\
\text { culture positive }\end{array}$ \\
\hline 14 & $43 / \mathrm{F}$ & No & $\begin{array}{l}\text { Pasta, sweet potato, } \\
\text { soybeans, peanuts, } \\
\text { fish }\end{array}$ & $\begin{array}{l}\text { Excision of terminal } \\
\text { ileum and cecum, } \\
\text { recovered }\end{array}$ & Discrete ulcers of the cecum & Gram stain of necrotic mucosa \\
\hline 15 & $12 / \mathrm{M}$ & $\begin{array}{l}\text { Type I, poorly } \\
\text { controlled }\end{array}$ & $\begin{array}{l}\text { Chitterling (pig } \\
\text { intestines) }\end{array}$ & $\begin{array}{l}\text { Excision of jejunum } \\
\text { and ileum }\end{array}$ & $\begin{array}{l}\text { Bloody ascites, extensive } \\
\text { mucosal and submucosal } \\
\text { necrosis of jejunum and } \\
\text { ileum }\end{array}$ & $\begin{array}{l}\text { Gram stain of necrotic mucosa } \\
\text { and PCR for gene products of } \\
\text { toxins }\end{array}$ \\
\hline CC & $66 / \mathrm{F}$ & $\begin{array}{l}\text { Type II, } \\
\text { controlled }\end{array}$ & Turkey sausage & $\begin{array}{l}\text { Died } 65 \mathrm{~h} \text { after } \\
\text { ingestion of sausage }\end{array}$ & $\begin{array}{l}\text { Autopsy: extensive segmental } \\
\text { mucosal \& transmural } \\
\text { necrosis of jejunum \& ileum }\end{array}$ & $\begin{array}{l}\text { Gram stain of necrotic mucosa } \\
\text { \& PCR for gene products of } \\
\text { toxins }\end{array}$ \\
\hline
\end{tabular}

CC, current case; PCR, polymerase chain reaction; M, male; F, female.

patients in the United States have been reported who developed small-intestinal necrosis $(19,20)$. It was postulated that the intestinal injury was the result of ischemia secondary to venous thrombosis caused by changes in the viscosity of the blood or sympathetic overactivity. Clostridial infection was not investigated as a causative factor in these cases, but the clinical and pathologic findings were remarkably similar to $C$. perfringens, Type $C$ enteritis necroticans.

The exposure to the infectious agent is likely to be fairly common, and yet even among diabetics, enteritis necroticans is extraordinarily rare. The metabolic condition of the previously reported child with poorly controlled Type 1 diabetes might be reflective of a state of malnutrition (15), but this cannot be said of the patient in our case, whose glucose was thought to be adequately controlled. A well-recognized complication of diabetes is reduced gastric and small intestinal motility, caused by autonomic dysfunction in which there is a delay in small-intestinal transit time (21-24). This reduced gastrointestinal motility is associated with overgrowth of bacteria that are normally present in the proximal small bowel (22). Our patient had also self-administered the antidiarrheal agent Imodium (loperamide), which inhibits gastrointestinal peristaltic activity and potentially contributed to clostridial overgrowth and an accumulation of toxin in the gut. Also, diabetics may have impaired ability to degrade exogenous toxins because of decreased secretion of pancreatic protease. A significant decrease in pancreatic enzymes and bicarbonate secretions was noted in 10 patients with Type 2 diabetes after maximal stimulation with secretin and cholecystokinin instilled into the jejunum (24). These patients had diabetes for an average of 13 years. It was postulated that these functional abnormalities were caused by atrophy of the pancreatic acini or by diabetic microangiopathy (25). The gross and microscopic examination of the pancreas in our patient did not show any significant pancreatic acinar atrophy but did show a severe diabetic microangiopathy.

The clustering of diabetes among these cases indicates a susceptibility to enteritis necroticans that is not present in the general population or among other chronically ill individuals. This emphasizes a need for diabetics to be cautious about eating or preparing foods that may harbor $C$. perfringens, Type C. Because successful treatment can be initiated after the onset of symptoms, enteritis necroticans should be considered in the differential diagnosis of the chronically ill and particularly in diabetics presenting with bloody diarrhea or an acute abdomen.

Acknowledgment: Illustrations were prepared by John Coleman, Ph.D., M.D. 


\section{REFERENCES}

1. Fick KA, Wolken AP. Necrotic jejunitis. Lancet 1949;1:51921.

2. Cooke RA. Pig bel. In: Rosenberg HS, Bolande RP, eds. Perspectives in pediatric pathology. Vol 5. New York: Masson; 1979. p. 137-52.

3. Zeissler J, Rassfeld-Sternberg L. Enteritis necroticans due to Clostridium welchii type F. Br Med J 1949;1:267-9.

4. Songer JG. Clostridial enteric diseases of domestic animals. Clin Microbiol Rev 1996;9:216-34.

5. Murrell TGC, Roth L. Necrotizing jejunitis: a newly discovered disease in the highlands of New Guinea. Med J Aust 1963;1:61-9.

6. Murrell TGC, Roth L, Egerton J, Samels J, Walker PD. Pig-bel. Enteritis necroticans. A study in diagnosis and management. Lancet 1966;219-22.

7. Egerton JR, Walker PD. The isolation of Clostridium perfringens type $C$ from necrotic enteritis of man in Papua-New Guinea. J Pathol Bact 1964;88:275-8.

8. Murrell TGC, Walker PD. The pigbel story of Papua New Guinea. Trans R Soc Trop Med Hyg 1991;85:119-22.

9. Murrell TGC. Enteritis necroticans. In: Finegold SM, George NL (editors). Anaerobic infections in humans. New York: 1989. p. 639-59.

10. Murrell TGC. Pigbel-epidemic and sporadic necrotizing enteritis in the highlands of New Guinea. Aust Annu Med 1967;1:4-10.

11. Severin WPJ, Fuente AA, Sringer MF. Clostridium perfringens type C causing necrotizing enteritis. J Clin Pathol 1984;37: $942-4$.

12. Watson DA, Andrew JH, Banting S, Mackay JR, Stillwell RG, Merrett M. Pig-bel but no pig: enteritis necroticans acquired in Australia. Med J Aust 1991;155:47-50.

13. Clarke LE, Diekmann-Guiroy B, McNamee W, Java DJ, Weiss SM. Enteritis necroticans with midgut necrosis caused by Clostridium perfringens. Arch Surg 1994;129:557-60.
14. Farrant JM, Traill Z, Conlon C, Warren B, Mortensen N, Gleeson FV, et al. Pigbel-like syndrome in a vegetarian in Oxford. Gut 1996;39:336-7.

15. Petrillo TM, Beck-Sague CM, Songer G, Abramowsky C, Fortenberry JD, Meacham L, et al. Enteritis necroticans (pigbel) in a diabetic child. N Engl J Med 2000;342:1250-3.

16. Songer JG, Meer RR. Genotyping of Clostridium perfringens by polymerase chain reaction is a useful adjunct to diagnosis of clostridial enteric disease in animals. Anaerobe 1996;2: 197-203.

17. Meer RR, Songer JG. Multiplex polymerase chain reaction assay for genotyping Clostridium perfringens. Am J Vet Res 1997;58:702-5.

18. Lawrence G, Cooke R. Experimental pigbel: the production and pathology of necrotizing enteritis due to Clostridium welchii type C in the guinea-pig. Br J Exp Pathol 1980;61: 261-71.

19. Chan-Cua S, Jones KL, Lynch FP, Freidenberg GR. Necrosis of the ileum in a diabetic adolescent. J Pediatr Surg 1992;27: 1236-8.

20. Nicol KK, Davis GJ. An unusual complication of diabetes mellitus: the zebra that became a horse. South Med J 1997; 90:83-5.

21. Camilleri M, Malagelada JR. Abnormal intestinal motility in diabetics with the gastroparesis syndrome. Eur J Clin Invest 1984;14:420-7.

22. Spengler U, Stellaard F. Ruckdeschel G, Scheurlen C, Kruis W. Small intestinal transit, bacterial growth, and bowel habits in diabetes mellitus. Pancreas 1989;4:65-70.

23. Enck P, Frieling T. Pathophysiology of diabetic gastroparesis. Diabetes 1991;46(Suppl 2):S77-81.

24. El Newihi H, Dooley CP, Saad C, Staples J, Zeidler A, Valenzuela JE. Impaired exocrine pancreatic function in diabetes with diarrhea and peripheral neuropathy. Dig Dis Sci 1988; 33:705-10.

25. Henderson JR, Daniel PM, Fraser PA. The pancreas as a single organ. Gut 1981;22:158-67. 